\title{
Argümantasyon Tabanlı Fen Öğretiminin Öğrencilerin Bilimsel Süreç Becerileri ve Akademik Başarılarına Etkisi $^{1}$
}

\author{
Seda ER \\ Milli Eğitim Bakanlığı \\ er.sedaa@gmail.com \\ Talip KIRINDI \\ Kırıkkale Üniversitesi \\ talipkirindi@yahoo.com
}

Gönderilme Tarihi: 09/05/2020

Kabul Tarihi: $26 / 11 / 2020$

Yayınlanma Tarihi: 30/11/2020

DOI: 10.30855 /gjes.2020.06.03.004

\begin{tabular}{l}
\hline Makale Bilgileri \\
\hline Anahtar Kelimeler: \\
Argümantasyon \\
tabanlı fen öğretimi, \\
Fen bilimleri eğitimi, \\
Akademik başarı
\end{tabular}

\begin{abstract}
ÖZET
Bu çalışmada, argümantasyon tabanlı fen öğretimi ve sorgulamaya dayalı öğrenme ile hazırlanan Fen Bilimleri dersinin öğrencilerin bilimsel süreç becerilerine ve akademik başarılarına etkilerinin belirlenmesi amaçlanmıştır. Bunun yanı sıra öğrencilerin argümantasyon tabanlı fen öğretimi hakkındaki görüşleri incelenmiştir. Araştırmanın çalışma grubunu, 2017-2018 eğitim-öğretim yılının güz döneminde öğrenim gören 6. sınıf öğrencileri oluşturmaktadır. Araştırmada bir deney $(n=25)$, bir kontrol $(n=25)$ grubu olmak üzere iki grup yer almıştır. Kontrol grubu öğrencileri öğretim programına uygun ders kitabındaki aktiviteleri gerçekleştirirken deney grubunda argümantasyon tabanlı fen öğretimi aktiviteleri gerçekleştirilmiştir. Çalışma amaçları doğrultusunda nicel ve nitel verilerin bir arada kullanıldığı karma araştırma deseni kullanılmıştır. Bu kapsamda araştırmanın nicel boyutunda ön testson test yarı deneysel desen kullanılırken araştırmanın nitel boyutunda ise betimsel analiz yöntemi kullanılmıştır. Çalışmanın nicel verileri, ön test-son test şeklinde uygulanan "Bilimsel Süreç Beceri Testi" ve "Fen Bilimleri Başarı Testi" aracılığıyla toplanmıştır. Nitel boyutta ise öğrencilerin argümantasyon tabanlı fen öğretimi uygulamaları hakkındaki görüşlerini belirlemek amacıyla yarı yapılandırılmış "Argümantasyon Görüşme Formu" kullanılmıştır. Nicel verilerin analizinde ilişkili (bağımlı) t-testi ve ilişkisiz (bağımsız) t-testi yapılırken nitel verilerin analizi ise içerik analizi tekniği kullanılmıştır. Nicel verilerin analiz sonuçlarına göre; argümantasyon tabanlı fen öğretimine göre hazırlanmış ders planlarının işlendiği deney grubu öğrencilerinin kontrol grubu öğrencilerine göre bilimsel süreç becerilerinin gelişiminde ve akademik başarı durumları üzerinde olumlu etkiye sahip olduğu ortaya çıkmıştır. Argümantasyon tabanlı fen öğretimi alan öğrencilerin görüşleri nicel sonuçları destekler niteliktedir. Ayrıca öğrenciler görüşlerinde argümantasyon eğitiminin öğrenmeye etkisi kapsamında bilgiyi desteklediği ve derse karşı tutum ve motivasyonu artırdığı yönünde olumlu görüş belirtmişlerdir.
\end{abstract}

1 Bu araştırma Prof. Dr. Talip KIRINDI danışmanlığında yürütülen Seda ER'in yüksek lisans tezinden üretilmiştir.

Er, S., \& Kırındı, T. (2020). Argümantasyon tabanlı fen öğretiminin öğrencilerin bilimsel süreç becerileri ve akademik başarılarına etkisi. Gazi Eğitim Bilimleri Dergisi, 6(3), 317-343.

DOI: https://dx.doi.org/110.30855/gjes.2020.06.03.004

Dergi Web Sayfası: http://dergipark.gov.tr/gebd 


\section{The Impact of the Argumentation Method Based Science Course on Students' Science Process Skills}

\begin{tabular}{ll}
\hline \hline Article Info & ABSTRACT \\
\hline Keywords: & In this study, the researcher aimed to determine the effects of the science course that \\
pased science & prepared via the argumentation-based learning method and the questioning-based \\
learning, & learning method, to the scientific-process skills of the students and their academic \\
Academic success, & achievements. Furthermore, we also examined the view of students about \\
Science education & argumentation-based learning. The study consisted of 6th-grade student participants \\
that taught in 2017-2018 education year in fall semester. The study included two \\
groups whose success levels are similar to each other. One of them is treatment group \\
(n=25) and the other one is control group (n=25) The study has been carried out \\
within the scope of the science course. While control group was instructed by the \\
activities in the book that is appropriate with curriculum, the experiment group \\
instructed by the argumentation-based science learning activities. To obtain \\
quantitative data researcher used "scientific process ability Scale" and "sciences \\
achievement Scale" which has been applied as a pre-test-post-test method. To obtain \\
qualitative data, we used semi-structured "argumentation interview form" with the \\
aim to define students' views about argumentation-based science teaching. For the \\
analysis of quantitative data, whilst we used dependent t-test and independent t-test, \\
for qualitative data, we used content-analysis technique. According to quantitative \\
data analysis results, it has been found that argumentation-based learning had \\
positive impact on students' academic success levels in their progress of scientific \\
process skills. Students' views also supported these results. Besides, students stated \\
positive opinions in their views that argumentation education promotes knowledge \\
and increase the motivation towards the lesson.
\end{tabular}

\section{GİRIŞ}

Bilimsel tartışma uygulamalarının ya da uluslararası alan yazında ve fen bilimleri dersi öğretim programında bilinen adıyla argümantasyonun, fen bilimleri eğitimi araştırmalarında öne çıktığı görülmektedir (Lee, Wu ve Tsai, 2009).

Günümüzde bireylerden öğrendikleri yeni bilgiyi var olan bilgi ve beceri ile yapılandırmaları beklenmektedir. Bu nedenle öğrencilerin bilgiyi yapılandırmadan önce ön bilgilerinin ortaya çıkarılması son derece önemlidir (Yahşi, 2006). Çünkü öğrencilerin ön bilgileri ölçülmeden, bu bilgiler üzerinde durulmadan, eksiklikler tamamlanmadan bilginin öğrencilere direkt verildiği ve ayrıca alışılagelmiş sınavlarla öğrencilerin değerlendirilmeye çalışıldığı öğrenme ortamlarında yetiştirilen bireylerin bilgiyi anlamlandırma ve kendi kendilerine oluşturabilmeleri noktasında zorluk yaşamaları olasıdır (Dalkıran, Kesercioğlu ve Boyacı, 2005). Bu açıdan bakıldığında farklı öğrenme ve öğretme yöntemleri öğrencilerin kendi öğrenmelerine ve bilgiyi yapılandırmalarına yardımcı olmalıdır (Günel, Uzoğlu ve Büyükkasap, 2009). Argümantasyon tabanlı fen öğretimin de bu doğrultuda araştırma-sorgulama stratejileri ile uyumludur ve düşünmeye, algılamaya önem veren süreçleri desteklemektedir (Hohenshell, 2004). 
Driver, Newton ve Osborne (2000) argümantasyonun eğitimin bir parçası olarak kullanılma sebebi; öğrencilerin konuyu sadece bilmesini değil, "diğer olaylarla ilişkisi nedir, niçin önemlidir?" boyutlarını da öğrencide oluşturmaya çalışmasından kaynaklandığını belirtmektedir. Argümantasyon, öğrencinin inandığı bilimsel bir fikri savunması ve karşıt görüşü elindeki bilimsel verilerle çürütmeye çalışmasının esas olduğu, iki veya daha fazla kişinin argümanları eleştirdiği ve yapılandırdığı sosyal bir süreçtir (Nussbaum, 2002). Literatürde argümantasyon tabanlı fen eğitimine yönelik çalışmalar incelendiğinde; argümantasyonun eğitimin ayrılmaz bir parçasını olduğunu ve öğrencinin argümanları yapılandırmasında etkili bir yöntem olduğunu göstermektedir (Balcı, 2015; Dawson ve Venville, 2007; Demirel, 2014; Kaya, 2009; Tekeli, 2009).

Eğitim literatüründe Keys, Hand, Prain ve Collins (1999) tarafından ortaya atılan bilimsel yazma uygulamalarının, ülkemizde Günel (2006) tarafından uyarlanması ve geliştirilmesi ile argümantasyon tabanlı fen öğretiminin yapısı oluşmuştur (Akkuş, Günel ve Hand, 2007; Günel, Kabataş-Memiş ve Büyükkasap, 2010; Kıngır, Geban ve Günel, 2013). Bu yapıda, sorgulamaya dayalı bir öğrenme ortamında öğrenciler sorular sorar, iddialar oluşturur ve iddialarını delillerle destekleyerek bilgiyi yapılandırırlar (Günel, Kıngır ve Geban, 2012).

Argümantasyon tabanlı fen öğretiminin (ATFÖ) uygulandığı ortamlarda öğrencilerin problem çözmedeki akıl yürütme mekanizmaları, problem durumu karşısında karar verme becerileri gelişmektedir. Ayrıca bunlara ek olarak bilgiyi yapılandırırken kullandıkları yöntemler ve ortamdaki bireylerle kurdukları sosyal etkileşim ve iletişim becerilerinin geliştiği de görülmektedir. ATFÖ; fen öğrenme için biliş ve üst biliş yaklaşımlarını bünyesinde bulundurur ve öğrencilerin veri, yöntem, delil ve iddialar arasında bağlantı kurma ve savunduğu iddiaları formüle etme, çıkarımda bulunma, destekleme gibi süreçleri yazma içerisinde harmanlamalarını sağlar (Hohenshell, 2008).

Fen eğitiminin amacı eleştirel, yansıtıcı, sorgulayıcı ve yaratıcı düşünen öğrenciler yetiştirmektir. Fen sınıflarında argümantasyon ortamının oluşturulması öğrencilerin bilimsel bilgiyi anlamalarına ve oluşturmalarına kılavuzluk edecektir (Deveci, 2009). Çünkü fen öğrenme yolu olarak argümantasyonun kullanımı gücünü bilimin ve bilimsel araştırma-sorgulamanın doğasından almaktadır (Qhobela ve Moru, 2011). Bilimsel argümantasyon, bilimsel bilginin geliştirilmesi, değerlendirilmesi ve geçerliliğini sağlamada merkezi bir rol oynar (Duschl ve Osborne, 2002). Bu nedenle özellikle, öğretim sürecinde aktif olarak bilimsel argümantasyonu kullanmak önerilmektedir.

Kuhn ve Udell (2003), argümantasyon tabanlı fen öğretim etkinliklerinin öğrencilere sağladığı bazı yararları şu şekilde belirtmiştir: i. Alternatif bakış açılarının farkına varma, ii. Fenni konuşma ve yazma, iii. Bilimsel okuryazarlık, iv. Eleştirel düşünme, v. Bilimsel düşünme, vi. 
Karar verme, vii. Aktif öğrenme, viii. Sosyal becerilerin gelişmesi, ix. Derinlemesine anlayış getirme, x. Bilime karşı olumlu tutum geliştirmedir.

Argümantasyon tabanlı fen öğretimi araştırma-sorgulama aktivitelerinin gerçekleştiği laboratuvar ortamında kullanıldığında, aktif öğrenci merkezli öğrenme çevreleri sağlar (Hand ve Keys, 1999; Keys vd., 1999). Argümantasyon tabanlı fen öğretimi, öğrencilerin fen kavramlarını daha iyi inşa etmesine yardım eden bir yaklaşımdır (Keys vd., 1999) ve onların süreçte düşünce olarak bağımsız olmalarını sağlar. Argümantasyon tabanlı fen öğretimi modelinin uygulandığı laboratuvarlarda yapılan deneyler ve araştırma yolları öğretmen rehberliğinde öğrenci şekillendirmektedir.

Toulmin argüman modeli Fen bilimleri eğitimi araştırmalarında sıklıkla başvurulan (Erduran, Simon ve Osborne, 2004; Bell ve Linn, 2000; Sampson ve Clark, 2008), öğrencilerin tartışma ögelerini ve karmaşıklığını belirlemek için eğitimciler tarafından yararlanılan bir tartışma modeli olarak ifade edilmiştir. Bu model ile öğrenciler süreç içerisinde bilgileri anlamlandırma, yorumlama, eleştiri yapma, yapılandırma ve yeni bilgilere ulaşma süreçlerini yaşarlar. Bununla birlikte öğretmenlerin öğrencileri bilişsel ve psikomotor yönlendirebilmesine de katkı sağlar.

Toulmin (1958), önerdiği modelde argümantasyonun temel bileşenlerini iddia, veriler, gerekçeler, destekleyiciler, çürütücüler ve sınırlayıcılar altı ögeden oluşmaktadır. Toulmin' in tartışma modeli Şekil 1 'de sunulmuştur.

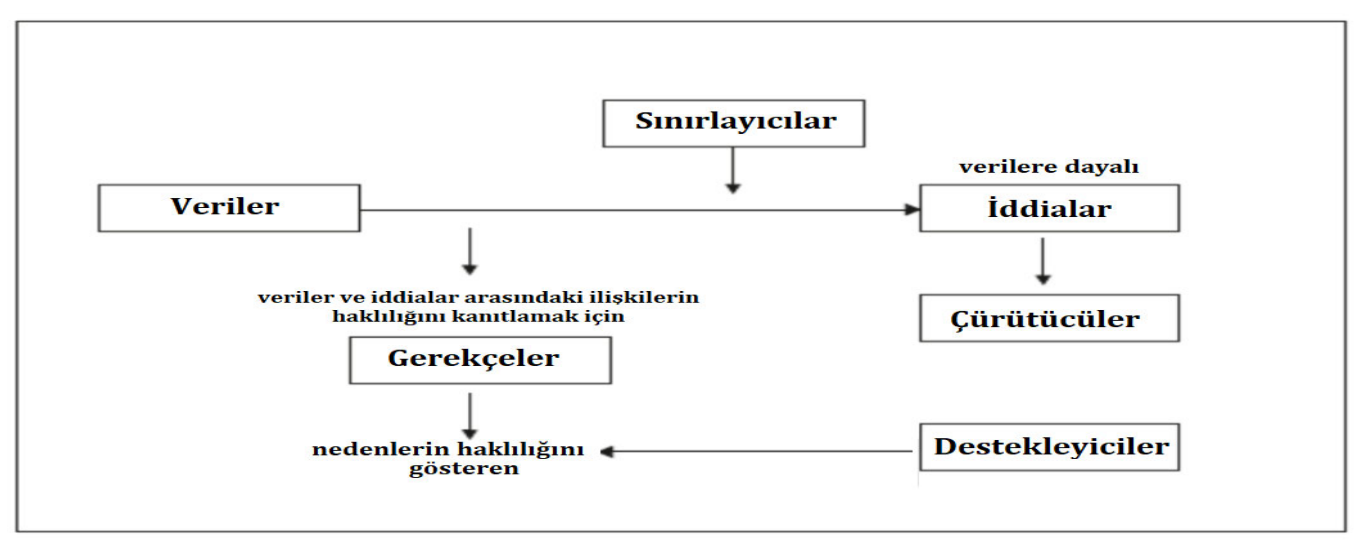

Şekil 1. Toulmin Tartışma Modeli (Toulmin, 1958)

Bu modelin bilimsel bir argümanında, iddia, verilere dayalı ortaya konulan sonuçlardır, tartışmanın temel amacıdır. Veri, varsayıma dayalıdır ve iddiayı desteklemeye yöneliktir. Gerekçe, veri ile iddianın arasındaki ilişkinin kanıtlanmasını sağlayan kurallar veya prensiplerdir. Destekleyiciler, argümanda sunduğunuz gerekçeyi haklı çıkarmak üzere sunulan geçerliği yaygın olarak kabul gören temel varsayımlar ya da kuramsal ifadelerdir. Sınırlayıcılar, iddianın doğru sayılabileceği durumları belirleyip iddianın sınırlarını çizen ve argümanın geçerli 
olduğu düzeyi belirler. Çürütücüler de, iddianın geçerli olamayacağı durumlara işaret ederek, argümanın sınırlılıklarını belirten ve argümanın kalitesini yükselten bileşendir (Erduran, Simon ve Osborne, 2004; Kaya ve Kılıç, 2008).

Toulminin tartışma modelinin temel yapısında ikna etmek yatar. Bununla birlikte öğrencilerin tartışmanın özünü anlamalarını sağlar, bir tartışmanın nasıl yürütülmesi gerektiğini kavramalarına yardım eder (Lazarou, 2009). Argümantasyon modeli akıl yürütme ve tartışma becerilerinin gelişmesini sağlar. Buna karşın Driver vd. (2000), Toulmin argüman modelinin sınırlılıklarından dolayı almış olduğu eleştirileri şu şekilde ifade etmişlerdir: i. Tartışma sürecinde aynı ifade farklı bir içerik içinde farklı bir anlama gelebilir, bu nedenle anlam çıkarabilmek için içeriğin dikkate alınması gerekir. ii. Tartışma sürecinde bazı ögeleri açıkça ifade edilmezler, çoğu zaman ima edilir. iii. Tartışma sürecinin doğal akış yaklaşımda olduğu gibi sıra içerisinde ilerlemeyebilir. Bu durumda tartışma sürecinde verilerin analizi zorlaşabilir. iv. Tartışmayı etkileyecek etkenlerin (jest, mimik, el kol hareketi), tartışmanın değerlendirme kısmında ve kuramların bütünleştirilmesinde yer alması gerekmektedir.

Diğer taraftan Toulmin'in argüman modelinin birçok yararı bulunmaktadır. Driver vd.'ne (2000) göre Toulmin' in argüman modelinin birçok sınırlılıklarından dolayı eleştiri getirilse de bu modelin önemli kısımlarını (bileşenlerini) aşağıdaki gibi sıralanmaktadır: i. Öğrenciler öğrenme sürecine aktif katılıp, sürecin bir parçası olarak üzerine düşen görev ve sorumlulukları yerine getirir. ii. Süreç içerisinde öğrenen bir öğrenci, araştırdığı konunun doğasını algılar, bu sayede konuları kavramsal olarak daha etkili anlar. iii. Öğrencilerin yorumlama becerileri gelişir ve analiz, sentez, değerlendirme gibi üst düzey düşünme becerileri kazanır. iv. Bir sorunun tek bir çözüm yolu olmadığını anlayıp, alternatif çözümleri fark eder. v. Öğrencilerin özgür bir şekilde düşündüklerini ifade edebilmelerini, kendilerine güvenmelerini, konuya farklı bakış açılarından bakmalarını sağlar. vi. Süreç sonunda öğrenciler sosyal yönleri gelişmiş güçlü bireyler olmaktadır. vii. Bilimsel tartışma ile öğrencilerin farklı görüşlere saygısı gelişir. Eleştiri yapma ve eleştirileri hoşgörü ile karşılama yetenekleri de gelişir. vii. Öğrenciler kendilerini kontrol etmeyi, disiplinli davranmayı öğrenip bilim insanlarının çalışma prensiplerine uygun çalışmalar sergileme firsatı yakalarlar.

\section{ATFÖ Uygulama Süreci}

\section{1. Öğretmen Süreci}

- Öğretmen sürecin başlangıcında öğrencilerin ön bilgilerini ortaya çıarmaya yönelik süreç planlar.

- Öğrencilerin daha etkin katılabilecekleri ve her öğrencinin süreçte konuşma fırsatının olacağ1 şekilde uygulama sürecini yönetir. 
- Uygulamalar için gerekli materyalleri temin eder.

- Araştırılan probleme yönelik farklı çözüm önerileri oluşturabilmeleri için öğrencileri küçük gruplar şeklinde çalışma ortamını oluşturur.

- Süreçte aktif olan öğretmen, öğrencilerin sundukları kanıtların uygulamalar sırasında oluşturdukları iddiaya yönelik olup olmadığını düşünmelerini sağlar.

- Süreç devam ederken öğrencilerin uygulamaları anlayıp anlamadıklarına yönelik soru sorar (Keys vd., 1999).

\section{ATFÖ Öğrenci Süreci}

- Öğrenciler araştırmak istedikleri soruları ve süreci kendileri oluşturur.

- Oluşturdukları sorulara cevap bulabilmek adına bir süreç tasarlarlar.

- Uygulamaları süresinde elde ettiği verilerini kaydeder.

- Buldukları veriler ve gözlemleri dâhilinde iddia ve delillerini oluştururlar.

- Grup arkadaşları ile tartışma sürecine girer, birbirlerini dinler ve kendi düşünceleri doğrultusunda soru sorar.

- Uygulamalarında ortaya çıkan sonuçla paralel bilgileri veren kaynakları araştırır gerekirse bir uzmandan yardım alabilirler (Akkuş vd., 2007; Keys, 1999).

\section{Argümantasyon Tabanlı Fen Öğretiminde Bilimsel Süreç Becerileri ve Akademik Başarı}

Fen eğitiminin amacı öğrencilere bilgiyi doğru aktarmak ve bilgiye ulaşma yollarını öğretebilmektir. Bunun içinde öğrencilerden araştırma ve sorgulama becerilerini geliştirmeleri beklenmektedir. Öğrencilere bilimin doğasını anlamaları, bilim insanlarının nasıl çalıştıklarını öğrenmeleri, bilimsel çalışma yöntemlerini kavramaları, bilimsel süreç becerilerini kazanmaları ve geliştirmeleri için zengin öğrenme ortamları hazırlanmalıdır.

Bilimsel süreç becerilerini geliştiren öğrenciler, bilgiye daha etkin ulaşır ve bilgiyi daha etkili bir şekilde anlamlandırabilir ve yapılandırabilir. Bilimsel süreç becerilerinin kazandırılması ve geliştirilmesi için planlı ve sistematik bir fen eğitimi uygulanabilir. Bilimsel süreç becerileri, Çepni, Ayas, Johnson ve Turgut'a (1996) göre fen bilimlerinde öğrenmeyi kolaylaştıran, öğrencilerin aktif olmasını sağlayan, kendi öğrenmelerinde sorumluluk alma duygusunu geliştiren, öğrenmenin kalıcılığını artıran ayrıca araştırma yol ve yöntemlerini kazandıran temel becerilerdir. Bilimsel süreç becerileri, gözlem yapabilme, elde edilen verileri ölçme, sinuflama ve kaydedebilme, hipotez kurabilme, verileri kullanarak model oluşturabilme, kontrollü deney yapabilme gibi bilim insanlarının gösterdikleri becerileri kapsamaktadır (MEB, 2013). 
Başarının, bireyin tüm yaşamında etkisini göstermesi mümkündür. Başarı, istenilen bir sonuca ulaşma yönünde bir ilerlemedir (Wolman 1973, Akt. Sünbül ve Gürsel, 2001). Akademik başarı ise, belirli bir program sonucunda öğrencinin program hedeflerine ilişkin gösterdiği yeterlilik düzeyidir (Demirel, 1994). Öğrencinin başarısını; okul deneyimleri, aile ortamı, öğrenci tutumları ve çevresindeki kişilerin bilime verdiği önem gibi değişkenlere bağlamaktadır. Öğrencinin fen başarısını etkileyen özellikleri iki grupta incelemektedir (Martinez, 2002): 1. Yaşantısal (deneyimsel) özellikler (fenle ilgili dersler almak ve evdeki fen kaynakları gibi). 2. Duyuşsal özellikler (fenne yönelik tutum, fenle ilgili kalıplaşmış fikirler, ailenin desteği ve akran etkisi gibi).

Eğitim hedefleri doğrultusunda öğrencilerin akademik başarı kazanmaları son derece önemlidir. Turgut (1988), göre akademik başarıyı ölçebilmek öğrencinin hedef davranışı göstereceği ölçme durumu oluşturmak ve ortaya çıkan davranışı gözlemleyip incelemek gerekmektedir. Kaya (2009), tarafından yapılan araştırma sonuçlarına göre bilimsel süreç becerilerinin en fazla geliştiği grup bilimsel tartışma etkinliklerinin yapıldığı grup olurken, başarı testi sonuçlarına göre de bilimsel tartışma etkinliklerinin yapıldığı grup diğer gruplardan daha başarılı olmuştur. Ceylan (2010), çalışmada elde edilen bulgular sonucunda, argümantasyon eğitiminin öğrencilerin başarılarını olumlu etkilemiş ve öğrencilerin derse daha aktif katılım sağladıklarını belirtmiştir. Cin (2013), tarafından yapılan araştırma sonucunda argümantasyona dayalı kavram karikatürü etkinliklerinin yapıldığı deney grubundaki öğrencilerinin kontrol grubundaki öğrencilere göre daha iyi yapılandırdıkları ve deney grubundaki öğrencilerin bilimsel süreç becerilerinin kontrol grubundaki öğrencilere göre daha iyi olduğu ortaya çıkmıştır. Deney grubundaki öğrencilerin konuyla ilgili kavramları daha iyi öğrendikleri belirlemiştir. Öğreten (2014), tarafından yapılan çalışmada bilimsel tartışma yöntemi (argümantasyon) öğrencilerin akademik başarılarını arttırdığını ve bilimsel tartışma becerilerini olumlu yönde etkilediğini bulmuştur. Ayrıca öğrencilerin Toulmin'in tartışma modelinde yer alan öğeleri kullanım düzeylerinde artış gözlenmiştir. Bu bağlamda fen eğitiminde argümantasyon kullanımının öğrencilerin bilişsel ve duyuşsal açıdan birçok kazanımında olumlu etkileri olduğu görülmektedir.

Fen bilimleri öğretim programlarının temelinde çoğunlukla bilgiyi zihinde anlamlandıran, sorgulayan, eleştiren ve iddialarını tartışabilen birey yetiştirme amacı vardır, MEB (2017) bu amacını Ortaokul Fen Bilimleri Öğretim Programı'nda “Sosyo-bilimsel konuları kullanarak muhakeme yeteneği, bilimsel düşünme alışkanlıkları ve karar verme becerileri geliştirmek" kazanımı ile açıkça belirtmiştir. Öğrencilerin bu becerileri kazanabilmeleri için gerekli ortamlar oluşturulmalıdır. İstenilen ortamın özelliklerini içinde bulunduran yöntemlerden bir tanesi argümantasyon tabanlı fen öğretimidir. Çalışmada, Fen Bilimleri dersinde kullanılan 
argümantasyon tabanlı fen öğretiminin öğrencilerin bilimsel süreç becerilerine ve akademik başarılarına etkisini belirlemek ve öğrencilerin argümantasyon tabanlı fen öğretimine yönelik görüşlerini ortaya çıkarmak amaçlanmıştır. Bu amaç kapsamında aşağıdaki araştırma sorularının cevapları aranmıştır.

1. Argümantasyon tabanlı fen öğretiminin deney grubu öğrencilerinin bilimsel süreç becerilerine ait ön test ve son test puanlarını arasında istatistiksel olarak anlamlı bir farklılık var midir?

2. Sorgulamaya dayalı öğrenmenin kontrol grubu öğrencilerinin bilimsel süreç becerilerine ait ön test ve son test puanlarının arasında istatistiksel olarak anlamlı bir farklılık var mıdır?

3. Argümantasyon tabanlı fen öğretiminin deney grubu öğrencilerinin akademik başarılarına ait ön test ve son test puanlarının arasında istatistiksel olarak anlamlı bir farklılık var mıdır?

4. Sorgulamaya dayalı öğrenmenin kontrol grubu öğrencilerinin akademik başarılarına ait ön test ve son test puanlarının arasında istatistiksel olarak anlamlı bir farklılık var mıdır?

5. Deney ve kontrol gruplarındaki öğrencilerin bilimsel süreç becerilerine ait ön test ve son test puanlarının ortalamaları arasında istatistiksel olarak anlamlı bir fark var mıdır?

6. Deney ve kontrol gruplarındaki öğrencilerin akademik başarıya ait ön test ve son test puanlarının ortalamaları arasında istatistiksel olarak anlamlı bir fark var mıdır?

7. Öğrencilerin argümantasyon tabanlı fen öğretimi kapsamındaki etkinliklere yönelik görüşleri nelerdir.

\section{YÖNTEM}

Çalışmada nicel ve nitel yöntemin birlikte kullanıldığı karma yöntem araştırması kullanılmıştır. Karma yöntem araştırmaları, araştırmacının bir çalışma veya birbirini izleyen çalışmalar içerisinde nitel ve nicel yöntem, yaklaşım ve kavramları birleştirmesi olarak tanımlanır (Creswell, 2003; Johnson ve Onwuegbuzie, 2004; Tashakkori ve Teddlie, 1998). Greeno vd.'ne (2005) göre karma yöntemler, aynı zamanda araştırmacının daha anlaşılır bir tasarım yapabilmesine olan gereksinimi de karşılamak için geliştirilmiştir.

Araştırmanın nicel yönteminde deneysel yöntem türlerinden yarı deneysel yöntem kullanılmıştır. Yarı deneysel yöntem deney ve kontrol gruplarına göre yerleşecek kişilerin rastgele dağılım dışında bir yolla yerleştirildiği desen türüdür. Büyüköztürk vd., (2008)’ e göre yarı deneysel desen seçkisiz atamanın yapılamayacağı durumlarda ciddi bir alternatif desendir. Deney ve kontrol gruplarına ön test ve son test sırasında aynı ölçme araçları kullanılmaktadır. Uygulanan deneysel desende bağımlı değişkenler bilimsel süreç becerileri ve akademik başarı testi olarak belirlenmiştir. Belirtilen bağımlı değişkenler üzerinde etkisi 
incelenen bağımsız değişken ise argümantasyon tabanlı fen öğretimi kapsamında geliştirilen etkinlikler olmuştur. Öğrencilerin bilimsel süreç becerileri ve akademik başarılarındaki değişimi inceleyebilmek amacıyla Bilimsel Süreç Beceri Testi (BSBT) ve Fen Bilimleri Başarı Testi (FBBT) araştırmada yer alan bütün öğrencilere ön test ve son test olarak uygulanmıştır. Araştırmanın nitel boyutunda ise deney grubuna yönelik görüşme formu kullanılmıştır. Elde edilen bulgular, içerik analizi ile değerlendirilmiştir. İçerik analizini, Büyüköztürk vd., (2008) belirli kurallara dayalı kodlamalarla, bir metnin bazı sözcüklerinin daha içerik kategorileri ile özetlendiği sistematik, yinelenebilir bir teknik olarak tanımlanmaktadır. Araştırmanın nicel boyutunda elde edilen verileri desteklemek amacıyla araştırma sonunda öğrenci görüşlerine başvurulmuştur.

\section{Çalışma Grubu}

Bu araştırma Ankara ilinde bulunan bir ortaokulda 2017-2018 eğitim - öğretim yılı güz döneminde öğrenim gören başarı düzeyleri birbirine yakın 6.sınıf öğrencileri oluşturmaktadır. Araştırmada bir deney $(n=25)$, bir kontrol $(n=25)$ olmak üzere iki grup yer almıştır. Kontrol grubu öğrencileri öğretim programına uygun ders kitabındaki aktiviteleri gerçekleştirirken deney grubunda argümantasyon tabanlı fen öğretimi aktiviteleri gerçekleştirilmiştir.

Tablo 1.

Çalışma grubu öğrencilerinin frekans ve yüzde dağılımları

\begin{tabular}{lcc}
\hline Grup & Frekans (f) & Yüzde (\%) \\
\hline Deney & 25 & 50 \\
Kontrol & 25 & 50 \\
Toplam & 50 & 100 \\
\hline
\end{tabular}

\section{Veri Toplama Araçları}

\section{Nicel Veri Toplama Araçları}

Araştırmada nicel verilerin toplanabilmesi, araştırmanın değerlendirilmesi, öğrencilerin bilimsel süreç becerileri ve akademik başarı durumlarının uygulama öncesi ve sonrası istatistiksel olarak anlamlı bir farklılık olup olmadığını ölçmek amacıyla "Bilimsel Süreç Beceri Testi" ve "Fen Bilimleri Başarı Testi" kullanılmıştır.

Etki büyüklüğü, bağımsız değişkenin ya da faktörün bağımlı değişkendeki toplam varyansın ne kadarını açıkladığını gösterir ve ortalama puanların karşılaştırılmasında hipotez testi sonuçlarının yorumlanmasında kullanılır.

$$
\mathrm{d}=\mathrm{t} \sqrt{\frac{N 1+N 2}{N 1 . N 2}}
$$

Cohen standardize edilmiş etki büyüklüğü indeksi olan d değeri karşılaştırılan ortalamaların birbirlerinden kaç standart sapma uzaklaştığını yorumlama imkanı verir. İşaretine bakılmaksınız d değeri ,2, ,5 ve ,8 olmak üzere sırasıyla küçük (small), orta (mediıum) 
ve geniş (large) etki büyüklüğü olarak yorumlanır. d değeri, potansiyel olarak, - $\infty$ ile $+\infty$ arasında alabilir. Bu değerlerle bağımsız değişkenin bağımlı değişken üzerinde ne derece etkili olduğu yorumlanabilir.

\section{Bilimsel Süreç Beceri Testi (BSBT)}

Araştırma kapsamında öğrencilere bilimsel süreç becerilerinin kazandırılması hedeflenmiştir. Bu hedef kapsamında, öğrencilerin bu becerilere ne derece sahip olduğunu belirlemek için Türker (2011) tarafından geliştirilen “Bilimsel Süreç Beceri Testi kullanılmıştır. Bilimsel süreç beceri testinin güvenirliği K-20 katsayısı ile ölçülmüş ve testin güvenilirliği 0.71 olarak hesaplanmıştır.

\section{Fen Bilimleri Başarı Testi}

Fen bilimleri başarı testi ilköğretim 6. Sınıf Fen Bilimleri dersi öğretim programında yer alan "Madde ve Isı" ünitesinin "Maddenin Tanecikli Yapısı" bölümüne yönelik uzman görüşü alınarak hazırlanmıştır. İlköğretim 6. sınıf öğrencilerinin algılama düzeyi düşünülerek, testte yer alan sorular üzerinde dil, okunabilirlik ve seçeneklerin çeldiriciliği bağlamında gerekli düzenlemeler yapılmıştır. Kazanımlar değerlendirildikten sonra hazırlanan sorular, çoktan seçmeli 20'şer madde olarak hazırlanmıştır ve her doğru cevap için " 1 ", her yanlış cevap için de " 0 " puan verilmiştir. Fen bilimleri başarı testinin güvenirliği K-20 katsayısı ile ölçülmüş ve testin güvenirliği 0.73 olarak hesaplanmıştır.

\section{Nitel Veri Toplama Araçları}

Araştırmada nitel verilerin toplanabilmesi, araştırmanın değerlendirilmesi, öğrencilerin argümantasyon tabanlı fen öğretimi kapsamındaki aktivitelere yönelik görüşlerinin değerlendirilmesi amaciyla "Argümantasyon Görüşme Formu", "ATFÖ raporları”, söz konusu raporları değerlendirmek için ATFÖ raporlarını değerlendirme rubriği kullanılmıştır.

\section{Argümantasyon Görüşme Formu, ATFÖ Raporları ve ATFÖ Raporları}

\section{Değerlendirme Rubriği:}

Uygulamanın nitel boyutunda ele alınan argümantasyon tabanlı fen öğretimi yaklaşımı hakkındaki görüşleri belirlemek ve uygulama sonrası nitel verileri desteklemek amacıyla öğrenci görüşlerine başvurulmuştur. Bu görüşleri belirlemek amacıyla yarı yapılandırılmış Argümantasyon Görüşme Formu hazırlanmıştır. Yarı yapılandırılmış görüşme tekniğinin araştırmacıya sunduğu en önemli kolaylık görüşmenin önceden hazırlanmış görüşme protokolüne bağlı olarak sürdürülmesi ile daha sistematik ve karşılaşılabilir bilgi sunmasıdır (Yıldırım ve Şimşek, 1999). Sorular araştırmacı tarafından hazırlanmış ve kapsam geçerliliği uzman öğretim üyeleri tarafından onaylanmıştır. Öğrencilere 3 açık uçlu soru yöneltilerek 
ATFÖ ile ilgili yapılan laboratuvar çalışmalarına dair bilgileri hakkında bilgi toplanıp, bu bilgiler organize edilip yorumlanarak araştırma bulgularına ulaşıldığı için içerik analizi üzerinde çalışılmıştır. Hazırlanan Argümantasyon Görüşme Formu uygulamaların bitiminde uygulanmıştır.

Uygulama süresince deney grubundaki öğrencilere her bir deney için Keys, Hand, Prain ve Collins (1999) tarafından geliştirilen ve Demirbağ (2011) tarafından araştırmasında kullanılan argümantasyon tabanlı deney raporu hazırlatılmıştır. Uygulama sırasında hazırlanan ATFÖ raporlarını değerlendirmek için analitik rubrik (Choi, 2008) kullanılmıştır. EK-1' de rubrik örneği yer almaktadır. Söz konusu değerlendirme rubriğinde "Sorular açık ve anlaşır mı?" ve “Başlangıç Düşüncesi- Yansımlar; düşüncelerinin değişmesinin ya da değişmemesinin nedenini ifade edebilmiş mi?" arasındaki maddeler göz önünde bulundurularak değerlendirme yapılmıştır. Burada öğrencilerin oluşturdukları soru, iddia ve kanıtlarının kalitelerinin yanı sıra uygulama sonrasında elde ettikleri verilerin sınıftaki arkadaşlarının da uygulamalar sonrasında elde ettikleri verileri ve o konuyla ilgili araştırılan literatür bilgisi arasındaki benzerlik ve farklılıklar anlamlı hale getirilmeye çalışılmıştır.

\section{BULGULAR}

\section{Nicel Bulgular}

\section{Bilimsel Süreç Becerileri Testine İlişkin Bulgular ve Yorum}

Deney ve kontrol grubunda bulunan öğrencilerine ön ve son test olarak uygulanan bilimsel süreç becerileri testinden aldıkları toplam puanların normal dağılımları Tablo 2' de verilmiştir.

Tablo 2.

Bilimsel Süreç Beceri Testi Normallik Testine İlişkin Bulguları

\begin{tabular}{ccccccc}
\hline \multirow{2}{*}{ Testler } & \multicolumn{3}{c}{ Kolimogorov-Smirnov } & \multicolumn{3}{c}{ Shapiro-Wilk } \\
& İstatistik & $\mathbf{S d}$ & $\mathbf{p}$ & İstatistik & $\mathbf{S d}$ & $\mathbf{p}$ \\
\hline Öntest_ortalama & 0,113 & 50 & 0,146 & 0,970 & 50 & 0,236 \\
Sontest_ortalama & 0,107 & 50 & 0,200 & 0,949 & 50 & 0,032 \\
\hline
\end{tabular}

Tablo 2 incelendiğinde, deney ve kontrol gruplarındaki öğrencilerin, bilimsel süreç becerileri testinin ön test ve son test uygulamalarından aldıkları toplam puanların normal dağılım gösterdiği ( $p>0.05)$ anlaşılmaktadır. Bu nedenle araştırmada elde edilen verilerin parametrik testler ile değerlendirilebileceğini göstermektedir (Büyüköztürk, 2017).

Tablo 3.

Deney ve Kontrol Grubu Öğrencilerinin Ön Test Bilimsel Süreç Becerileri Düzeylerine İlişkin Bulgular

\begin{tabular}{lcccccc}
\hline Ön test & $\mathbf{N}$ & $\overline{\mathbf{X}}$ & $\mathbf{S}$ & $\mathbf{s d}$ & $\mathbf{t}$ & $\mathbf{p}$ \\
\hline Deney & 25 & 0,422 & 0,129 & 48 & 0,239 & 0,813 \\
Kontrol & 25 & 0,414 & 0,106 & & & \\
\hline
\end{tabular}

Tablo 3 de incelendiğinde kontrol grubunun uygulama öncesinde bilimsel süreç 
becerileri testinden aldığ puan $X=0,414$ iken, deney grubu öğrencilerinin uygulama öncesinde bilimsel süreç becerileri testinden aldıkları puanların $X=0,422^{\prime}$ dir. Yapılan analizde uygulama öncesi deney ve kontrol grubunun bilimsel süreç becerileri testi sonuçları arasında anlamlı bir farklılık olmadığı görülmüştür $(\mathrm{t}(48)=0,239, \mathrm{p}>0,05)$.

Tablo 4.

Kontrol Grubu Öğrencilerinin Ön Test-Son Test Bilimsel Süreç Becerileri Düzeylerine İlişkin Bulgular

\begin{tabular}{lccccccc}
\hline Ön test & $\mathbf{N}$ & $\overline{\mathbf{X}}$ & $\mathbf{S}$ & $\mathbf{s d}$ & $\mathbf{t}$ & $\mathbf{p}$ & Cohen $\mathbf{d}$ \\
\hline Öntest & 25 & 0,414 & 0,106 & 24 & $-2,17$ & 0,039 & 0,61 \\
Sontest & 25 & 0,470 & 0,158 & & & & \\
\hline
\end{tabular}

Tablo 4 de incelendiğinde kontrol grubunun uygulama öncesinde bilimsel süreç becerileri testinden aldığı puan $\overline{\mathrm{X}}=0,414$ iken, uygulama sonrası bilimsel süreç becerileri testinden aldıkları puanların $\bar{X}=0,470^{\prime}$ dir. Yapılan analizde kontrol grubunun ön test ve son test toplam puanlarının anlamlı bir farklılık olup olmadığını sınamak için yapılan bağımlı $t$ testi analizi anlamlı bir farklılık göstermektedir $(t(24)=2.17 p>0,05)$. Bağımsız gruplar $t$-testi için hesaplanan etki büyüklüğü sonuçlarına benzer şekilde Tablo 4'te belirtilen Cohen d değeri 0,61 olarak hesaplanmıştır ve "küçük" etki büyüklüğü olduğu görülmüştür.

Tablo 5.

Deney Grubu Öğrencilerinin Ön Test-Son Test Bilimsel Süreç Becerileri Düzeylerine İlişkin Bulgular

\begin{tabular}{lccccccc}
\hline Deney & $\mathbf{N}$ & $\overline{\mathbf{X}}$ & $\mathbf{S}$ & $\mathbf{s d}$ & $\mathbf{t}$ & $\mathbf{p}$ & Cohen $\mathbf{d}$ \\
\hline Öntest & 25 & 0,422 & 0,129 & 24 & 6,47 & 0,00 & 1,83 \\
Sontest & 25 & 0,556 & 0,176 & & & & \\
\hline
\end{tabular}

Tablo 5 de incelendiğinde deney grubunun uygulama öncesinde bilimsel süreç becerileri testinden aldığı puan $\overline{\mathrm{X}}=0,422$ iken, uygulama sonrası bilimsel süreç becerileri testinden aldıkları puanların $\bar{X}=0,556^{\prime}$ dir. Yapılan analizde deney grubunun ön test ve son test toplam puanlarının önemli bir farklılık olup olmadığını sınamak için yapılan bağımlı $t$ testi analizi anlamlı bir farklılık göstermektedir $(t(24)=6,47 ; p<0,05)$. Anlamlı farklılık, deney grubu öğrencilerinin bilimsel süreç becerileri testi aldıkları son test puanları yönündedir. Cohen $\mathrm{d}$ değeri 1,82 olarak hesaplanmıştır ve "küçük" derecede etki büyüklüğüne sahiptir.

Tablo 6.

Deney ve Kontrol Grubu Öğrencilerinin Son Test Bilimsel Süreç Becerileri Sonuçlan Düzeylerine İlişkin Bulgular

\begin{tabular}{lcccccc}
\hline Sontest & $\mathbf{N}$ & $\overline{\mathbf{X}}$ & $\mathbf{S}$ & $\mathbf{s d}$ & $\mathbf{t}$ & $\mathbf{p}$ \\
\hline Deney & 25 & 0,556 & 0,176 & 48 & 1,82 & 0,075 \\
Kontrol & 25 & 0,470 & 0,158 & & & \\
\hline
\end{tabular}

Tablo 6 incelendiğinde kontrol grubunun uygulama sonrasında bilimsel süreç becerileri 
testinden aldığı puan $\bar{X}=0,470$ iken, deney grubu öğrencilerinin uygulama sonrasında bilimsel süreç becerileri testinden aldıkları puanların $\bar{X}=0,556$ ' dir. Yapılan analizde uygulama sonrası deney ve kontrol grubunun bilimsel süreç becerileri testi sonuçları arasında anlamlı bir farklılık olmadığı görülmüştür $(\mathfrak{t}(48)=1,82 \mathrm{p}<0,05)$. Gruplar arasında anlamlı bir farklılığın bulunmamasının sebebi, kontrol grubu öğrencileriyle mevcut öğretim programına göre yani öğrenci merkezli etkinliklerin gerçekleştirilmesidir.

\section{Fen Bilimleri Başarı Testine İlişkin Bulgular ve Yorum}

Deney ve kontrol grubu öğrencilerinin fen bilimleri başarı düzeylerine ilişkin verileri Tablo 7 'de verilmiştir.

Tablo 7.

Deney ve Kontrol Grubu Öğrencilerinin Ön Test Fen Bilimleri Başarı Düzeylerine İlişkin Bulgular

\begin{tabular}{lcccccc}
\hline Öntest & $\mathbf{N}$ & $\overline{\mathbf{X}}$ & $\mathbf{S}$ & $\mathbf{s d}$ & $\mathbf{t}$ & $\mathbf{p}$ \\
\hline Deney & 25 & 0,244 & 0,130 & 48 & 1,21 & 0,231 \\
Kontrol & 25 & 0,202 & 0,113 & & & \\
\hline
\end{tabular}

Tablo 7'de verildiği gibi öğrencilerin uygulama öncesinde vermiş oldukları cevaplarda toplam puanların ortalamalarının anlamlı bir farklılık gösterip göstermediğini sınamak için yapılan $\mathrm{t}$ testi analizi anlamlı bir farklılık göstermemektedir $(\mathrm{t}(48)=1,21 \mathrm{p}>0,05)$. Kontrol grubu öğrencilerinin uygulama öncesinde başarı testinden aldıkları puanların $\bar{X}=0,202$ iken, deney grubu öğrencilerinin uygulama öncesinde başarı testinden aldıkları puanların $\overline{\mathrm{X}}=0,244^{\prime}$ dir.

Tablo 8.

Kontrol Grubu Öğrencilerinin Ön Test-Son Test Fen Bilimleri Başarı Düzeylerine İlişkin Bulgular

\begin{tabular}{lccccccc}
\hline Kontrol & $\mathbf{N}$ & $\overline{\mathbf{X}}$ & $\mathbf{S}$ & $\mathbf{s d}$ & $\mathbf{t}$ & $\mathbf{p}$ & Cohen d \\
\hline Öntest & 25 & 0,202 & 0,113 & 24 & 8,64 & 0,00 & 2,44 \\
Sontest & 25 & 0,424 & 0,179 & & & & \\
\hline
\end{tabular}

Tablo 8' de kontrol grubu öğrencilerinin ön test-son test fen bilimleri başarı düzeylerine ilişkin bulgular elde edilmiştir. Yapılan analiz kontrol grubunun ön test- son test fen bilimleri başarı düzeylerine ilişki anlamlı bir farklılık göstermektedir $(t(24)=8,64 p>0,05)$. Cohen $d$ değeri 2,44 olarak hesaplanmıştır ve "küçük" dereceden fazla etki büyüklügüne sahiptir. Kontrol grubu öğrencilerinin uygulama öncesinde başarı testinden aldıkları puanların $\bar{X}=0,202$ iken, uygulama sonrasında başarı testinden aldıkları puanların $\overline{\mathrm{X}}=0,424^{\prime}$ dür.

Tablo 9.

Deney Grubu Öğrencilerinin Ön Test-Son Test Fen Bilimleri Başarı Düzeylerine İlişkin Bulgular

\begin{tabular}{lccccccc}
\hline Deney & $\mathbf{N}$ & $\overline{\mathbf{X}}$ & $\mathbf{S}$ & $\mathbf{s d}$ & $\mathbf{t}$ & $\mathbf{p}$ & Cohen d \\
\hline Öntest & 25 & 0,244 & 0,130 & 24 & 9,06 & 0,00 & 2,56 \\
Sontest & 25 & 0,516 & 0,207 & & & & \\
\hline
\end{tabular}


Tablo 9'da deney grubu öğrencilerinin uygulama öncesinde ve sonrasında başarı testi sonucunda ortalamalar arasında anlamlı bir farklılık olup olmadığını göstermektedir. Deney grubu öğrencilerinin ön test ve son test toplam puanlarının anlamlı bir farklılık gösterip göstermediğini sınamak için yapılan $\mathrm{t}$ testi analizi anlamlı bir farklılık göstermektedir $(\mathrm{t}(24)=$ $9,06 \mathrm{p}<0,05)$. Anlamlı farklılık, deney grubu öğrencilerinin başarı testi aldıkları son test puanları yönündedir. Cohen d değeri 2,56 olarak hesaplanmıştır ve "küçük" dereceden fazla etki büyüklüğüne sahiptir. Yine bu gruba ait uygulama öncesi ve sonrası başarı testinden aldıkları puanları bu tabloda verilmiştir.

Tablo 10.

Deney ve Kontrol Grubu Öğrencilerinin Son Test Fen Bilimleri Başarı Düzeylerine İlişkin Bulgular

\begin{tabular}{lcccccc}
\hline Sontest & $\mathbf{N}$ & $\overline{\mathbf{X}}$ & $\mathbf{S}$ & $\mathbf{s d}$ & $\mathbf{t}$ & $\mathbf{p}$ \\
\hline Deney & 25 & 0,516 & 0,207 & 48 & 1,67 & 0,10 \\
Kontrol & 25 & 0,424 & 0,179 & & & \\
\hline
\end{tabular}

Tablo 10 'da uygulama sonrasında deney ve kontrol grubu öğrencilerinin başarı testi sonucunda ortalamalar arasında anlamlı bir farklılık olup olmadığını göstermektedir. Veriler analiz edildiğimde öğrencilerin uygulama sonrasında vermiş anlamlı bir farklılık göstermemektedir $(\mathrm{t}(48)=1,67 \mathrm{p}<0,05)$. Gruplar arasında anlamlı bir farklılığın bulunmamasının sebebi, kontrol grubu öğrencileriyle mevcut öğretim programına göre yani öğrenci merkezli etkinliklerin gerçekleştirilmesi olabilir. Kontrol grubu ve deney grubu öğrencilerine ait başarı testi puanları verilmiştir. Deney ve kontrol grubu öğrencilerinin başarı testi düzeylerinin gelişimini, başarı testinde yer alan sorular bazında inceleyebilmek için her soruya ilişkin frekans değerlerine Tablo 10 'da yer verilmiştir.

\section{Nitel Bulgular}

\section{Argümantasyon Raporlarına İlişkin Bulgular ve Yorum}

Raporlardan elde edilen bulgular sonucunda, öğrenciler soruları oluştururken açık ve anlaşılır, büyük düşünceleri çoğunlukla destekleyici nitelikte sorular oluşturmuştur. Başlangıç düşüncelerini akla yatkın bir şekilde açıklamıştır. Yapılan işlemlerde değişken kontrolü söz konusudur ve deney doğru bir şekilde soruları cevaplamak adına yapılmıştır. Deney sonucunda bulduklarını çoğunlukla tam olarak not etmişlerdir. İddialarını, açık ve anlaşılır, çoğunlukla bilimsel olarak doğru, bir kısmı verilerle aynı bir kısmı verilerden farklı bulmuştur. Delilleri, açık, anlaşılır ve bulgularla ilişkilidir. Kendi düşüncelerini sınıf arkadaşları ile paylaşmışlardır. Kaynaktan elde ettikleri bilgiler yapılan aktivitelerin temel düşüncesini yansıtıyor. Soru ve başlangıç düşünceleri arasında çoğunlukla tutarlılık vardır. Yaptıkları, buldukları ve delilleri arasında tutarlık vardır ve büyük bir kısmı hazırladıkları soruları cevaplamaya yöneliktir. Soru, iddia ve delilleri arasında da tutarlık vardır ve geliştirilen argüman büyük düşünceyi 
desteklemektedir. Kaynaktan elde edilen bilgiler iddia ile çoğunlukla tutarlıdır. Yansımaları başlangıç düşünceleri ile tutarlılık göstermektedir. Öğrenciler deney yapma, soru sorma, iddia ve delil oluşturma becerisi bakımından yeterlilik göstermiştir (Tablo 11).

Tablo 11.

Argümantasyon Raporlarına İlişkin Bulgular

\begin{tabular}{|c|c|c|c|c|c|}
\hline & 1.Grup (\%) & 2.Grup (\%) & 3.Grup (\%) & 4.Grup (\%) & 5.Grup (\%) \\
\hline Sorular & 30 & 48 & 32 & 48 & 36 \\
\hline $\begin{array}{l}\text { Başlangıç } \\
\text { düşünceleri }\end{array}$ & 14 & 22 & 20 & 24 & 14 \\
\hline Yaptıklarım & 30 & 42 & 38 & 48 & 32 \\
\hline Bulduklarım & 16 & 24 & 18 & 24 & 12 \\
\hline İddialarım & 44 & 60 & 66 & 72 & 66 \\
\hline Delillerim & 36 & 42 & 44 & 48 & 28 \\
\hline Snf. Ark. Notları & 12 & 18 & 22 & 24 & 16 \\
\hline Okuduklarım & 20 & 36 & 42 & 48 & 38 \\
\hline $\begin{array}{l}\text { Soru- Başlangiç } \\
\text { Düşüncesi }\end{array}$ & 18 & 16 & 20 & 24 & 12 \\
\hline $\begin{array}{l}\text { Yaptıklarım- } \\
\text { Bulduklarım- } \\
\text { Delillerim }\end{array}$ & 38 & 40 & 38 & 48 & 28 \\
\hline $\begin{array}{l}\text { Soru-İddia-Delil } \\
\text { Üçgeni }\end{array}$ & 49 & 51 & 71 & 72 & 46 \\
\hline $\begin{array}{l}\text { İddia- } \\
\text { Okuduklarım } \\
\text { Başlangıç }\end{array}$ & 18 & 21 & 24 & 24 & 19 \\
\hline $\begin{array}{l}\text { Düşüncesi- } \\
\text { Yansımalar }\end{array}$ & 30 & 34 & 48 & 48 & 28 \\
\hline
\end{tabular}

\section{Argümantasyon Görüşme Formlarına İlişkin Bulgular ve Yorum}

Öğrencilere uygulama sonrasında argümantasyon tabanlı fen öğretimi yaklaşımı hakkındaki görüşlerini belirlemek amacıyla Argümantasyon Görüşme Formu uygulanmıştır. Görüş formunda öğrencilerin argümantasyon tabanlı fen öğretimi yaklaşımı ortamında gerçekleştirilen argümantasyon eğitimi ve etkinlikler hakkındaki görüşlerini belirlemek amacıyla üç soru yöneltilmiştir. Öğrencilerin verdikleri cevaplardan kodlar belirlenmiştir.

\section{Tablo 12.}

Argümantasyon Eğitimi ve Etkinliklerin Uygulanmasına Ait Ana Tema ve Alt Temalar

\begin{tabular}{ll}
\hline \multicolumn{1}{c}{ Ana Tema } & \multicolumn{1}{c}{ Alt Tema } \\
\hline & Beceri Gelişimi \\
Argümantasyonun Öğrenmeye Etkisi & Bilginin Yapılandırılması ve \\
& Desteklenmesi \\
& Tutum ve Motivasyon Yönelimi \\
& Bilgi ve Beceriye Bağlı Güçlükler \\
Argümantasyonun Eğitimde Güçlükler & Etkinliğe Bağlı Güçlükler \\
& Olumsuz Tutum \\
\hline
\end{tabular}

Bu kodlar üzerinden öğrenci görüşlerine doğrudan atıf yapılarak yorumlanmıştır. 
Argümantasyon eğitimi ve etkinliklerin uygulanmasına ait ana tema ve bu temalara ait alt boyutlar Tablo 12.' de yer verilmiştir.

Öğrencilerden elde edilen bulgular incelenerek "Argümantasyonun Öğrenmeye Etkisi" ana temasına altında yer alan alt temalar, kodlar ve frekanslar tablo $13^{\prime}$ de verilmiştir. Öğrencilerin belirtmiş oldukları görüşlere göre beceri gelişimi temasının kodları, karar verme becerisi, grup çalışması, iletişim becerisi, işbirliği becerisi, düşünme becerisi ve problem çözme becerisidir. Bilginin yapılandırılması ve desteklenmesi temasının kodları, eğlenerek yapma, kalıcılık sağlama, etkili öğrenme sağlama, öğrenci merkezli olma, günlük hayatla ilişkilendirme, uygulama yapmak ve öğretici olmasıdır. Tutum ve motivasyon yönelimi temasının kodları ise derse ilgi, etkinliklerin beğenilmesi, zevk alma ve derse ilgidir.

Tablo 13.

Argümantasyonun Öğrenmeye Etkisi Ana Temasına Altında Yer Alan Alt Temalar, Kodlar ve Yüzdeler

\begin{tabular}{lll}
\hline Alt Tema & Kodlar & $\%$ \\
\hline \multirow{4}{*}{ Beceri Gelişimi } & Karar verme becerisi & 36 \\
& Grup çalışması & 32 \\
& İletişim becerisi & 24 \\
& İşbirliği becerisi & 16 \\
& Düşünme becerisi & 16 \\
& Problem çözme becerisi & 12 \\
\hline \multirow{3}{*}{ Bilginin Yapılandırılması ve } & Aktif katılım sağlar & 48 \\
Desteklenmesi & Eğlenerek yapma & 40 \\
& Kalıcılık sağlar & 32 \\
& Etkili öğrenme sağlar & 24 \\
& Öğrenci merkezli olması & 24 \\
& Günlük hayatla ilişkilendirme & 20 \\
Tutum ve Motivasyon Yönelimi & Uygulama yapmak & 12 \\
& Öğretici olması & 12 \\
\cline { 2 - 3 } & Derse ilgi & 56 \\
& Etkinliklerin beğenilmesi & 48 \\
& Zevk alma & 28 \\
& Derse ilgi & 14 \\
\hline
\end{tabular}

"Argümantasyon Eğitiminde Güçlükler" ana temasına altında yer alan alt temalar, kodlar ve frekanslar Tablo 14'de verilmiştir. Öğrencilerin belirtmiş oldukları görüşlere göre bilgi ve beceriye bağlı güçlükler temasının kodları, bilgi eksikliği, karar verme güçlüğü, grup içi iletişim kuramama ve iş birliği sağlayamamadır. Etkinliğe bağlı güçlükler temasının kodları, etkinliğin zor gelmesi ve etkinliğin uzun sürmesidir. Olumsuz tutum temasının kodları, yorucu olması ve etkinliklerde zorlanmadır. Sınırlılık temasının kodu ise ders süresinin yetersizliğidir. 
Tablo 14.

Argümantasyonun Öğrenmeye Etkisi Ana Temasına Altında Yer Alan Alt Temalar, Kodlar ve Yüzdeler

\begin{tabular}{llc}
\hline \multicolumn{1}{c}{ Alt Tema } & Kodlar & $\%$ \\
\hline \multirow{3}{*}{ Bilgi ve Beceriye Bağlı Güçlükler } & Bilgi eksikliği & 24 \\
& Karar verme güçlüğ̈̈ & 16 \\
& Grup içi iletişim kuramama & 12 \\
& Iş birliği sağlayamama & 12 \\
\hline \multirow{2}{*}{ Etkinliğe Bağlı Güçlükler } & Etkinliğin zor gelmesi & 12 \\
& Etkinliğin uzun sürmesi & 8 \\
\hline \multirow{2}{*}{ Olumsuz Tutum } & Yorucu olması & 4 \\
& Etkinliklerde zorlanma & 12 \\
\hline Sinırlılıklar & Ders süresi yetersizliği & 8 \\
\hline
\end{tabular}

“Geleneksel Fen Bilimleri dersi mi yoksa argümantasyon tabanlı Fen Bilimleri dersini mi tercih edersiniz? Neden?" sorusuna karşıllk öğrencilerin vermiş olduğu yanıtlar incelenmiştir. Öğrencilerin soruya verdikleri bazı cevaplar şöyledir:

Ö2: Argümantasyon yaklaşımı ile çok güzel etkinlikler yaptık.

Ö5: Argümantasyon tabanlı fen öğretimi diye bir şey daha önceden duymamıştım. Çok zorlanacağımı ve yapamayacağımı düşünüyordum ama hiç de öyle olmadı. Ders çok güzel ve eğlenceli geçti.

Ö8: Ders çok eğlenceli, öğretici geçti. Teşekkürler hocam.

Ö10: Argümantasyon ile ders çok harikaydı. Farklı bir şekilde deney yaptık. Çok hoşuma gitti.

Ö13: Hocam etkinlikler ile derse olan ilgim arttı. Teşekkür ederim hocam.

Ö16: Argümantasyon etkinlikleri çok sevdim, daha iyi öğrendim.

Ö21: Argümantasyon yöntemi ile ders eğlenceliydi. Grup çalışması ile deneyler yapmakta güzeldi.

Ö24: Argümantasyon ile deneyleri eğlenerek yaptım.

“Argümantsayon tabanlı Fen Bilimleri dersi etkinliklerinde kendi sorularınızı hazırlamanız, iddia ve kanıt oluşturmanız öğrenmenize katkı sağladı mı? Evet, ise nasıl katkısı oldu?" sorusuna karşılık öğrencilerin vermiş olduğu yanıtlar incelenmiştir. Öğrencilerin soruya verdikleri bazı cevaplar şöyledir:

Ö1: Derste öğrendiklerimizi uygulamak zevkli oldu.

Ö5: Soruları hazırlayabilmem öğrendiklerimin daha iyi aklımda kalmasını sağladı. İddialara kanıt bulmam da hayal gücümü geliştirdi.

Ö14: Soruları hazırlamak benim için güzel oldu. Çünkü kendim yaptım. İddialara kanıt ararken arkadaşlarımla beraber düşündük.

Ö15: Soruları arkadaşlarla hazırladık. İddialara kanıtları arkadaşlarla beraber düşündük.

Ö16: Soruları öğrendiklerimi düşünerek yaptım.

Ö18: Grup arkadaşlarımla farklı farklı düşünceler ortaya çıtı.

Ö21: Soruları, iddialara kanıtları grup arkadaşlarımla birlikte hazırlamak hoşuma gitti.

Ö23: Evet, çünkü kendimiz düşünerek yapıyoruz. 
Ö24: Soruları ve kanıtları ararken günlük hayattan şeyler düşündüm.

Öğrenci görüşlerinden de anlaşllacağı üzere argümantasyon tabanlı fen öğretimi ortamında gerçekleştirilen argümantasyon etkinliklerinin uygulanması sonucunda bireyler aktif katılım göstererek kendi fikirleri doğrultusunda çözümler ürettiğini bu nedenle de düşünme becerilerinin geliştiğini, takım çalışmasını desteklediğini ve geliştirdiğini, grup çalışmasını baz aldığı ve bireyler arası sürekli bir etkileşimin olması iletişim becerisinin bireylerde geliştiğini, Fen öğretiminde etkili olduğunu bu yüzden de eğitim sistemimiz için gerekli bir yöntem olduğunu sonucuna ulaştıklarını, işbirlikçi çalışmayı sağlayarak bireylerde işbirliği becerisinin geliştiğini, eğlenerek öğrendikleri, hayal güçlerini kullandıkları, derse olan ilgilerinin artmasına, kendi sorularını hazırlamaları, iddialarına kanıt bulmaları bir problem karşısında nasıl davranmaları gerektirdiği yönünde gelişme sağlamıştır.

"Uygulanan bu etkinliklerin hangi bölümlerinde zorlandınız? Sebepleri ile birlikte açıklayınız." maddesine karşılık öğrencilerin vermiş olduğu yanıtlar incelenmiştir. Öğrencilerin soruya verdikleri bazı cevaplar şöyledir:

Ö4: Argümantasyon etkinliklerinden biraz sıkıldım. Çünkü soru oluşturmakta ve kanıt bulmakta zorlandim.

Ö10: İddialara kanıt bulmakta zorlandım.

Ö14: Keşke süremiz daha uzun olsaydl.

Ö18: İddialara farklı farkl fikirler üretiyoruz. Karar veremiyoruz.

Ö20: Grup arkadaşlarım benim fikirlerimi dinlemedi ve düşündüğüm soruları yazmadılar.

Ö23: Soruları hazırlamakta zorlandım. İddialara kanıt bulmada zorlandım.

Öğrenci görüşlerinden de anlaşılacağı üzere argümantasyon tabanlı fen öğretimi ortamında gerçekleştirilen Argüman etkinlikleri sırasında grup içi iletişimi sağlayamadıkları için iletişim de güçlük yaşadıklarını bildirmişlerdir. Bu duruma birden fazla fikrin çıkması ve hangisinin iyi olduğuna karar verememelerinin sebep olduğu düşünülmektedir. Karar verme de güçlük yaşamalarını nedeni olarak da grup içi iletişimin sağlanamaması, bireylerin karar vermelerinde de sorun yaşamalarına sebep olduğu düşünülmektedir Ders süresinin yetersiz olması sonucu ise problem çözümü için gerekli aşamaları belirlenen ders süresi içerisinde yetiştirememeleri sebep olduğu düşünülmektedir. Karşılaşılan birçok sorunun temel sebebi olarak bilgi eksiklikleri gösterilmektedir. Bunun sebebi olarak teorik olarak bildiklerini uygulama esnasında kullanamamaları ve malzemeleri iyi bir şekilde tanımamaları uygulamalar sırasında güçlük yaşamalarına neden olduğu düşünülmektedir.

\section{TARTIŞMA VE SONUÇ}

“Öğrencilerin bilimsel süreç becerileri durumları arasında anlamlı bir farklılık var mıdır?” sorusunu araştırmak için öğrencilere, bilimsel süreç becerileri durumlarını belirlemek için 
Bilimsel Süreç Becerileri Testi ön test- son test olarak uygulanmıştır. Elde edilen sonuçlara göre öğrencilerin bilimsel süreç becerilerinin hem deney grubunda hem de kontrol grubunda artış gösterdiği ancak gruplar arasında bilimsel süreç becerileri açısından anlamlı farklılık olmadığı görülmüştür. Gruplar arasında anlamlı bir farklılığın bulunmamasının sebebi, kontrol grubu öğrencileriyle mevcut öğretim programına göre yani öğrenci merkezli etkinliklerin gerçekleştirilmesidir. Ancak literatür incelendiğinde, argümantasyon tabanlı öğrenme aktivitelerinin öğrencilerin bilimsel süreç becerilerini kazandırmada mevcut öğretim yöntemlerine göre daha etkili olduğu (Balcı, 2015; Cevger, 2018; Cin, 2013; Demirel, 2014; Gençoğlan, 2017; Öğreten, 2014) bazı araştırmalarda ise bu araştırmada olduğu gibi hem deney hem de kontrol grubu öğrencilerinin bilimsel süreç becerilerinin benzer şekilde artış gösterdiği görülmektedir. Araştırmada bilimsel süreç becerileri açısından gruplar arasında anlamlı farklılık olmadığ1 görülse de literatüre göre (Cin, 2013; Demirel, 2014; Gençoğlan, 2017; İşıker, 2017; Kaya, 2009) genel olarak argümantasyon tabanlı fen öğretimi ortamında argümantasyon eğitiminin bilimsel süreç becerileri kazandırılmasında ve geliştirilmesinde etkili olduğu görülmektedir. Ayrıca süreç içerisinde öğrencilerin başvurduğu argümanatasyon tabanlı bilim öğrenme basamaklarının entegre edildiği argümantasyon eğitimi sayesinde probleminin çözümü için etkili ve üretken düşünmelerini ve bir bilim insanı rolü üstlenip bilimsel bilgiye ulaşma amaçlarının bilimsel süreç becerilerinin üzerinde etkili olduğu görülmektedir. Deneylerin tasarlandığı argümantasyon tabanlı fen öğretimi yöntemiyle öğrencilere, ürün oluşturmaları, birçok fikrin içinden seçim yapmalarını, seçimlerini kanıtlarla desteklemelerini ve süreci rapor etmelerine imkân sunmuştur. Bu şekilde öğrenciler öğrenme sürecine aktif olarak katılmış ve kendileri için gerekli olan doğru bilgiye ulaşarak anlamlı öğrenme gerçekleştirmişlerdir.

"Öğrencilerin Fen Bilimleri Başarı Testi durumları arasında istatistiksel olarak anlamlı bir farklılık var mıdır?" sorusunu araştırmak için öğrencilere, Fen Bilimleri Başarı Testi ön test- son test olarak uygulanmıştır. Elde edilen sonuçlara göre öğrencilerin akademik başarılarının hem deney grubunda hem de kontrol grubunda artış gösterdiği ancak gruplar arasında akademik başarıları açısından anlamlı farklılık olmadığı görülmüştür. Gruplar arasında anlamlı bir farklılığın bulunmamasının sebebi, kontrol grubu öğrencileriyle mevcut öğretim programına göre yani öğrenci merkezli etkinliklerin gerçekleştirilmesidir. Ancak literatür (Cevger,2018; Ceylan, 2010, Öğreten, 2014) incelemesinde argümantasyon tabanlı fen öğretimi aktivitelerinin öğrencilerin akademik başarılarını artırmada mevcut öğretim yöntemlerine göre daha etkili olduğu görülmektedir. Arlan (2018), Aydoğdu (2017), Gülen ve Yaman (2018) ve İşıker (2017) ilkokul-ortaokul öğrencilerine; yönelik çalışmalarında argümantasyon eğitiminin bireylerin akademik başarılarına olumlu yönde katkı sağladığı ortaya çıkmıştır. Bazı araştırmalarda ise bu araştırmada olduğu gibi hem deney hem de kontrol grubu öğrencilerinin akademik başarılarının benzer şekilde artış gösterdiği görülmektedir. Argümantasyon tabanlı fen öğretimi ortamında 
öğrencilerin akademik başarı düzeylerinin gelişmesinde etkisi olduğu görülmektedir. Bununla birlikte deney grubunda bulunan öğrencilerin görüşleri incelendiğinde de argümantasyon eğitiminin öğrenci başarılarına katkı sağladığı söylenebilir. Bu yöntem ile öğrenciler eğlenerek, araştırarak, sorgulayarak, akranları ile tartışarak, verimli bir şekilde çalışabilmelerine ve arkadaşlarıyla düzenli ilişkiler kurmasını sağlayarak hem yaşamsal beceri kazanmalarına hem de güdülenmeyi artırarak akademik başarılarının artmasına katkı sağladığı ortaya çıkmaktadır.

“Öğrencilerin argümantasyon tabanlı fen öğretimi kapsamındaki aktivitelere yönelik görüşleri nelerdir?" sorusunu araştırmak için öğrencilere, amaca yönelik uygulama sonrası öğrenci görüşlerini açığa çıkarabilmek için araştırmacı tarafından geliştirilen "Argümantasyon Görüşme Formu" kullanılmıştır.

Öğrenci görüşlerinden uygulamalarla ilgili; argümantasyon tabanlı eğitimin öğrenmeye etkisine ve eğitiminde ortaya çıkardığı güçlüklere ulaşılmıştır. Argümantasyon tabanlı fen öğretiminin öğrencilerin; problem çözme becerisi, düşünme becerisi, takım çalışması, iş birliği becerisi, iletişim becerisi, karar verme becerisi, eğlenerek, yaparak yaşayarak öğrenmeye ve günlük hayatla ilişkilendirmeye katkı sağladığı sonucuna varılmıştır. Okumuş (2012) bilimsel tartışma modeline dayalı öğretimin yapılması hakkındaki öğrenci görüşlerine göre genel olarak bilimsel tartışma modeli ile ders işlemekten memnun olduklarını ve yapılan etkinliklerin öğrenmelerinin daha kalıcı olduğunu vurgulamıştır. Kaya (2005) argümantasyon tabanlı fen öğretimi modeli ile öğretimin öğrencilerin başarılarına ve bilimin doğasıyla ilgili kavramları anlamalarını araştırdığı çalışmasında, öğrencilerle argümantasyon modelinin etkililiği konusunda yaptı̆̆ı görüşmelere göre öğrencilerin argümantasyon tartışma modeli kapsamında yapılan etkinliklerin daha anlamlı ve kalıcı olduğunu belirtmiştir. Bununla birlikte argümantasyon eğitiminde, soruları belirleme, not tutmama, grup içi iletişim kurma, grup arkadaşlarının işbirliği içinde çalışmaması, ders süresinin eksikliği, deney yapma, karar verme ve bilgi eksikliği olması kaynaklı güçlüklerle karşılaşmıştır. Öğrencilerin argümantasyon eğitimi ve etkinlikleriyle ilk defa karşılaşmaları, etkinlikler sırasında güçlük yaşamalarında etkili olduğu şeklinde düşünülmektedir.

Literatür incelemesinde argümantasyon eğitiminin olumlu yönlerinden bahsedildiği gibi olumsuz yönlerinden de bahsedilmektedir. Gençoğlu (2017) bu olumsuzlukların; öğrencilerinin başlarda argüman oluşturma konusunda acemilik çekmeleri, bugüne kadar ezbere dayalı, geleneksel yöntemle uygulaması yapılan derslerin öğrencilerin bilim adamı gibi düşünmelerini zorlaştırdığı; ancak ATFÖ yaklaşımı uygulaması öğrencilerin uygulama süreci içerisinde, argüman oluşturma becerilerini geliştirdiği, bilimsel bilgiye ulaşmada istekliliklerini arttırdığı, öğrencilerin bir bilim adamı gibi düşünmeyi öğrendiklerini tespit etmiştir. Okumuş (2012) ise bu durumu, öğrencilerin uygulamaların ilk kısımlarında daha düşük seviyede tartışmalar 
oluştururken uygulamanın sonlarına doğru tartışma seviyelerinin arttığını, bu artışın öğrencilerin süreç içerisinde bu modele alışmasıyla modelin gerektirdiği uygulamaları daha etkili bir şekilde gerçekleştirerek sağladıklarını ifade etmiştir.

ATFÖ, öğrencilerin öğrenme sürecine katılımlarını artırmakta ve bu sebeple daha etkin bir öğrenme ortamı oluşturabilmektedir. Argümantasyon öğrencilerin bilim etkinliklerinde çalışırken muhakemeleri güçlendiren ve üst biliş desteği görevi yapan bir dizi aktiviteden oluşmaktadır. Argümantasyon tabanlı fen öğretimi ile öğrencilerin sosyal yargılama, üst düzey bilişsel becerileri, bilimsel kültürlenme, dili kullanma becerisini, bilimin doğasını anlama, bilimsel okuryazar olma, yaratıcı ve eleştirel düşünebilme ve araştırma-sorgulama becerileri kazandırdığı görülmektedir (Jimenez-Aleixander ve Erduran, 2007).

Yapılan araştırmaların sonucunda argümantasyon uygulamalarının fen öğretiminde önemli bir yere sahip olduğu ortaya çıkmaktadır. Öğretmenlere argümantasyonun fen öğretimindeki yeri hakkında bilgi ve verilmesi ve derslerde nasıl kullanacağınız öğretilmesi gerekli ve önemli görülmektedir.

\section{ÖNERILLER}

$\mathrm{Bu}$ bölümde araştırma bulguları sonucunda argümantasyon eğitimin geliştirilmesi açısından önemli olabilecek önerilere yer verilmiştir:

1. Öğrencilerin fenni daha iyi anlamaları için günlük yaşam ile daha çok ilişkilendirilerek ve argümantasyon tabanlı fen öğretiminin daha etkili uygulanabilmesi için gerekli süre sağlanarak bu tür çalışmalar uygulanabilir.

2. Uygulamalar sırasında argümantasyon tabanlı fen öğretimi ortamı kurulmuş ve argümantasyon etkinlikleri bu ortama entegre edilmiştir. Bu tür çalışmalarda öncelikle öğrencilerin bilgi eksikliğinin giderilebileceği, daha iyi iletişim kurabilecekleri, fikir alışverişinde bulunabilecekleri ortamlar hazırlanarak diğer kademelere yönelikte hedef kazanımlar belirlenerek yeniden tasarlanıp, uygulanabilir.

Öğrencilere bilimin doğasını anlamaları, bilim insanlarının nasıl çalıştıklarını öğrenmeleri, bilimsel çalışma yöntemlerini kavramaları, bilimsel süreç becerilerini kazanmaları ve geliştirmeleri için zengin öğrenme ortamları hazırlanabilir.

\section{KAYNAKLAR}

Akkuş, R., Günel, M., \& ve Hand, B. (2007). Comparing an inquiry-based approach known as the science writing heuristic to traditional science teaching practices: Are there differences? International Journal of Science Education, 14(5), 1745-1765.

Aslan, Ö. Y. (2018). Fen öğretiminde argümantasyon yönteminin kullanılmasının akademik başarı, bilimsel süreç ve problem çözme becerilerine etkisi. Yayınlanmamış Yüksek Lisans Tezi, Bülent 
Ecevit Üniversitesi, Zonguldak.

Aydoğdu, Z. (2017). Argümantasyon tabanlı öğretimin öğrencilerin fenne yönelik akademik başarı, motivasyon, ilgi ve tutumlarına etkisinin incelenmesi. Yayınlanmamış Yüksek Lisans Tezi, Sakarya Üniversitesi, Sakarya.

Balc1, M. (2015). Argümantasyon tabanl fen öğretiminin ilkokul 4. slmı öğrencilerinde etkililiğinin incelenmesi. Yayınlanmamış Doktora Tezi, Dumlupınar Üniversitesi, Afyonkarahisar.

Bell, P., \& Linn, M. C. (2000). Scientific arguments as learning artifacts: Designing for learning from the Web with KIE. International Journal of Science Education, 22(8), 797-817.

Büyüköztürk, Ş., Kılıç Çakmak, E., Akgün, Ö.E., Karadeniz, Ş., \& Demirel, F. (2008). Bilimsel araştırma yöntemleri. Ankara: Pegem Yayınları.

Büyüköztürk, Ş. (2017). Veri analizi el kitabı. Ankara, Pegem Akademi.

Cevger, F. (2018). Sosyal bilgiler dersinde argümantasyon tabanh öğrenme yönteminin kullanılmasının öğrencilerin akademik başarılarına, bilimsel düşünme becerilerine ve bilimsel tartışma düzeylerine etkisi. Yayınlanmamış Doktora Tezi, Atatürk Üniversitesi, Erzurum.

Ceylan, Ç. (2010). Fen laboratuvar etkinliklerinde argümantasyon tabanlı fen öğretimi yaklaşımının kullanımı. Yayınlanmamış Yüksek Lisans Tezi, Gazi Üniversitesi, Ankara.

Choi, A. (2008). A study of student written argument using the science writing heurssicc approach in inquiry-based freshman general chemistry laboratory classes. Unpublished Doctoral Dissertation, College of the University Of Iowa, USA.

Cin, M. (2013). Argümantasyon yöntemine dayalı kavram karikatürü etkinliklerinin öğrencilerin kavramsal anlama düzeylerine ve bilimsel süreç becerilerine etkileri. Yayınlanmamış Yüksek Lisans Tezi, Dokuz Eylül Üniversitesi, İzmir.

Creswell, J. W. (2003). Research design: Qualitative, quantitative, and mixed methods approaches (2nd ed.). Thousand Oaks, CA: Sage.

Çepni, S., Ayas, A., Johnson, D., \& Turgut, M. F. (1996). Fizik öğretimi. Ankara, Milli Eğitimi Geliştirme Projesi Hizmet Öncesi Öğretmen Eğitimi Deneme Basımı.

Dalkıran, G., Kesercioğlu, T., \& Boyacı, S. (2005). Kavram haritaları ve kavramsal değişim metinlerinin ögrencilerin fen bilgisi dersine olan tutumlarına etkisi ve öğrenci görüşleri. Ulusal Eğitim Bilimleri Kongresi, Pamukkale Üniversitesi, Denizli.

Dawson, V. M., \& Venville, G.J. (2007). Teaching strategies for developing students' argumentation skills about socio-scientific issues in high school genetics. Reasearch in Science Education, 40(2), 133-148.

Demirel, Ö. (1994). Genel öğretim yöntemleri, Ankara, USEM Yayınları.

Demirbağ, M. (2011). Argümantasyon tabanlı fen öğretimi yaklaşımının kullanıldığı Fen sinıflarında Modsal Betimleme eğitiminin öğrencilerin Fen başarlarn ve yazma becerilerine etkisi. Yayınlanmamış Yüksek Lisans Tezi, Ahi Evran Üniversitesi, Kırşehir. 
Demirel, O. E. (2014). Probleme dayalı öğrenme ve argümantasyona dayalı öğrenmenin öğrencilerin kimya dersi başarllarına, bilimsel süreç becerilerine ve bilimsel muhakeme yeteneklerine etkilerinin incelenmesi. Yayınlanmamış Yüksek Lisans Tezi, Mustafa Kemal Üniversitesi, Hatay.

Deveci, A. (2009). İlköğretim yedinci sımı öğrencilerinin maddenin yapısı konusunda sosyo-bilimsel argümantasyon, bilgi seviyeleri ve bilişsel düşünme becerilerini geliştirmek. Yayınlanmamış Yüksek Lisans Tezi, Marmara Üniversitesi, İstanbul.

Driver, R., Newton, P., \& Osborne, J. (2000). Establishing the norms of scientific argumentation in classrooms. Science Education, 84(3), 287-312.

Duschl, R.A., \& Osborne, J. (2002). Supporting and promoting argumentation discourse in science education. Studies in Science Education, 38, 39-72.

Erduran, S., Simon, S., \& Osborne, J. (2004). TAPping into argumentation: Developments in the application of Toulmin's Argument Pattern for studying science discourse. Science Education, 88(6), 915-933.

Gençoğlan, D.M. (2017). Otantik örnek olay destekli argümantasyon tabanl fen öğretimi yaklaşımının 8. sinıf öğrencilerinin asitler ve bazlar konusundaki başarlarına, tutum ve bilimsel süreç becerilerine etkisi. Yayınlanmamış Yüksek Lisans Tezi, Kahramanmaraş Sütçü İmam Üniversitesi, Kahramanmaraş.

Gülen, S., \& Yaman, S. (2018). Fen-teknoloji-mühendislik ve matematik eğitimi entegreli argümantasyon metinlerinden oluşan ürün dosyalarının değerlendirilmesi. Journal of STEAM Education, 1(2), 1-16.

Günel, M. (2006). Investigating the impact of teachers' implementation practices on academic achievement in science during a long-term professional development program on the Science Writing Heuristic. Yayınlanmamış Doktora Tezi, Lowa State University, Ames.

Günel, M., Uzoğlu, M., \& Büyükkasap, E. (2009). Öğrenme amaçl yazma aktivitelerinin kullanımının ilköğretim seviyesinde kuvvet konusunu öğrenmeye etkisi. Gazi Eğitim Fakültesi Dergisi, 29(1), 379-399.

Günel, M., Kabataş Memiş, E., \& Büyükkasap, E. (2010). Yaparak yazarak bilim öğrenimi-YYBÖ yaklaşımının ilköğretim öğrencilerinin fen akademik başarısına ve fen dersine yönelik tutumuna etkisi. Eğitim ve Bilim, 35(155), 49-62.

Günel, M., Kıngır, S., \& Geban, Ö. (2012). Argümantasyon tabanlı fen öğretimi (ATBÖ) yaklaşımının kullanıldığı sınıflarda argümantasyon ve soru yapılarının incelenmesi. Eğitim ve Bilim, 37(164), 316-330.

Greeno, J. G., Collins, A. M., \& Resnick, L. B. (1996). Cognition and learning. Handbook of educational psychology, 77: 15-46.

Hand, B., \& Keys, C. (1999). Inquiry investigation: A new approach to laboratory reports. The Science Teacher, 66, 27-29. 
Hohenshell, L. (2004). Enhancing science literacy though implementation of writing- to - learn strategies: Exploratory studies in high school biology. Unpublished Doctoral Dissertation, Iowa State University, USA.

Hohenshell, L. M. (2008). Scendory students' perception of the swh approach to nonconvential writing: Features that support learning of biology concepts and elements of scientific argumentation. In B. Hand (Ed.), Science Inquiry, Argument and Language (pp. 99-110). Rotterdam: Sense Publisher.

İşıker, Y. (2017). Maddeyi tanıyalım ünitesinde argümantasyon tabanlı öğretimin öğrencilerin akademik başarı, bilimsel süreç becerileri ve tutumlarına olan etkileri. Yayınlanmamış Yüksek Lisans Tezi, Frrat Üniversitesi, Elâzı̆̆.

Jiménez-Aleixandre, M. P., \& Erduran, S. (2007). Argumentation in science education: An Overview. In S. Erduran ve M. P. Jiménez-Aleixandre (Eds.), Argumentation in science education: Perspectives from classroom-based research, (pp.3-27). Springer, Dordrecht.

Johnson, R. B., \& Onwuegbuzie, A. J. (2004). Mixed methods research: A research paradigm whose time has come. Educational Researcher, 33(7): 14-26.

Kaya, O. N., \& Kılıç, Z. (2008). Etkin bir fen öğretimi için tartışmacı söylev. Ahi Evran Üniversitesi, Kırşehir Eğitim Fakültesi Dergisi, 9(3), 89-100.

Kaya, B. (2009). Araştırma temelli öğretim ve bilimsel tartışma yönteminin ilköğretim öğrencilerinin asitler ve bazlar konusunu öğrenmesi üzerine etkilerinin karşılaştırllması. Yayınlanmamış Yüksek Lisans Tezi, Marmara Üniversitesi, İstanbul.

Keys, C. W. (1999). Revitalizing instruction in scientific genres: Connecting knowledge production with writing to learn in science. Science Education, 83, 115-130.

Keys, C. W., Hand, B., Prain, V., \& Collins, S. (1999). Using the science writing heuristic as a tool for learning from laboratory investigations in secondary science. Journal of Research in Science Teaching, 36(10), 1065-1084.

Kingır, S., Geban, Ö., \& Günel, M. (2013). Using the science writing heuristic approach to enhance student understanding in chemical change and mixture. Research in Science Education, 43, 1645-1663.

Kuhn, D., \& Udell, W. (2003). The development of argument skills. Child development, 74(5), 12451260.

Lazarou, D. (2009). Learning to TAP: An effort to scaffold students' argumentation in science. Paper presented at 8. European Science Education Research Association (ESERA) Annual Conference, 31 August-4 September. İstanbul, Turkey

Lee, M. H., Wu, Y. T., \& Tsai, C. C. (2009). Research trends in science education from 2003 to 2007: A content analysis of publications in selected journals. International Journal of Science Education, 31(15), 1999-2020. 
Martinez, A. (2002). Student achievement in science: A longitudinal look at individual and school differences. Unpublished Doctoral Dissertation, Harvard University, London.

Milli Eğitim Bakanlığı (MEB). (2013). İköğretim kurumları (ilkokullar ve ortaokullar) fen bilimleri dersi $(3,4,5,6,7$ ve 8. sinıflar) öğretim programı. Ankara.

Milli Eğitim Bakanlığı (MEB). (2017). İlköğretim kurumlar (ilkokullar ve ortaokullar) fen bilimleri dersi, $(3,4,5,6,7$ ve 8. sinuflar) öğretim programı, Ankara.

Nussbaum, E. M. (2002). How introverts versus extroverts approach classroom argumentative discussions. The Elementary School Journal, 102, 183-197.

Okumuş, S. (2012). Maddenin halleri ve ısı ünitesinin argümantasyon modeli ile öğretiminin öğrenci başarısına ve anlama düzeylerine etkisi. Yayınlanmamış Yüksek Lisans Tezi, Karadeniz Teknik Üniversitesi, Trabzon.

Öğreten, B. (2014). Argümantasyona dayah öğretim sürecinin akademik başarı ve tartışma seviyelerine etkisi. Yayınlanmamış Yüksek Lisans Tezi, Amasya Üniversitesi, Amasya.

Qhobela, M., \& Moru, E. K. (2011). Learning physics through argumentation at secondary school level in Lesotho: a feasible teaching strategy, African Journal of Research in Mathemetics, Science and Technology Education, 15(2), 205-220.

Sampson, V., \& Clark, D. B. (2008). Assessment of the ways students generate arguments in science education: Current perspectives and recommendations for future directions. Science Education, 92, 447-472.

Sünbül, A. M., \& Gürsel, M. (2001). Başarılı ve başarısız lise 1.sınıf öğrencilerin öğrenilmiş çaresizlik ve problem çözme becerilerinin karşılaştırılması. Selçuk Üniversitesi, Eğitim Fakültesi Sosyal Bilimler Dergisi, 12, 352-363.

Tashakkori, A., \& Teddlie, C. (1998). Mixed methodology: Combining qualitative and quantitative approaches. Applied Social Research Methods Series (Vol.46). Thousand Oaks, CA: Sage.

Tekeli, A. (2009). Argümantasyon odakl sını ortamının öğrencilerin asit-baz konusundaki kavramsal değişimlerine ve bilimin doğasını kavramalarına etkisi. Yayınlanmamış Yüksek Lisans Tezi, Gazi Üniversitesi, Ankara.

Toulmin, S. E. (1958). The uses of argument. Cambridge: Cambridge University Press.

Turgut, M. F. (1988). Eğitimde ölçme ve değerlendirme metotları (6. Baskı), Ankara, Saydam Matbaacilı.

Türker, E. (2011). Bilimsel süreç becerileri yaklaşımının model kullanılarak uygulanmasının öğrencilerin başarılarına, bilimsel süreç becerilerinin gelişimine ve motivasyonlarına etkisi. Yayınlanmamış Yüksek Lisans Tezi, Karadeniz Teknik Üniversitesi, Trabzon.

Yahşi, D. (2006). Farklı laboratuvar yaklaşımlarının ilköğretim 8. sınıf öğrencilerinin asit-baz konularmndaki kavramlarn anlamalarnna ve kavram yanılgilarmın giderilmesine etkisi. Yayınlanmamış Yüksek Lisans Tezi, Abant İzzet Baysal Üniversitesi, Bolu. 
Yıldırım, A., \& Şimşek, H. (1999). Sosyal bilimlerde nitel araştırma yöntemleri. Ankara: Seçkin Yayınevi.

Etik Kurul Kararı: Bu araştırma yüksek lisans tezinden üretildiği için etik kurul kararı zorunluluğu taşımamaktadır. 
EK 1-Argümantasyon Tabanlı Fen Öğretimi Raporu Değerlendirme Rubriği

\begin{tabular}{|c|c|c|c|c|c|c|c|}
\hline Kod & Bölüm & Madde & 0 & 1 & 2 & 3 & Kod \\
\hline 101 & \multirow{2}{*}{ Sorular } & Açık ve anlaşılır mı? & & & & & 101 \\
\hline 102 & & Büyük düşünceleri hedefliyor mu? & & & & & 102 \\
\hline 103 & $\begin{array}{l}\text { Başlangı̧̣ } \\
\text { düşünceleri }\end{array}$ & Akla yatkın bir şekilde açıklanmış mı? & & & & & 103 \\
\hline 104 & \multirow{2}{*}{ Yaptıklarım } & $\begin{array}{l}\text { Yapılan işlemlerde değişken kontrolü söz konusu } \\
\text { mu? }\end{array}$ & & & & & 104 \\
\hline 105 & & $\begin{array}{l}\text { Deney doğru bir şekilde ve soruyu cevaplamak } \\
\text { adına yapılmış mı? }\end{array}$ & & & & & 105 \\
\hline 106 & Bulduklarım & Tamlık (formül, birim, grafik, metin) & & & & & 106 \\
\hline 107 & \multirow{3}{*}{ İddialarım } & Açık ve anlaşı1ır mı? & & & & & 107 \\
\hline 108 & & Bilimsel olarak doğru mu? & & & & & 108 \\
\hline 109 & & Delillerden/verilerden farklı mı? & & & & & 109 \\
\hline 110 & \multirow{2}{*}{ Delillerim } & Açık ve anlaşılır mı? & & & & & 110 \\
\hline 111 & & Bulgularla ilişkili mi? & & & & & 111 \\
\hline 112 & $\begin{array}{l}\text { Snf. Ark. } \\
\text { Notlar }\end{array}$ & $\begin{array}{l}\text { Kendi düşüncesi ile farklı düşünceleri karşılaştırmış } \\
\text { mı? }\end{array}$ & & & & & 112 \\
\hline 113 & \multirow[b]{2}{*}{ Okuduklarım } & Kullanılan kaynak sayısı? & & & & & 113 \\
\hline 114 & & $\begin{array}{l}\text { Kaynaktan elde edilen bilgi yapilan aktivitelerin } \\
\text { temel düşüncesini yansitıyor mu? }\end{array}$ & & & & & 114 \\
\hline 21 & \begin{tabular}{|l|} 
Soru- \\
Başlangıç \\
Düşüncesi
\end{tabular} & $\begin{array}{l}\text { Soru ve başlangıç düşünceleri arasındaki } \\
\text { tutarlılık }\end{array}$ & & & & & 21 \\
\hline 31 & \multirow{2}{*}{$\begin{array}{l}\text { Yaptıklarım } \\
\text { Bulduklarım } \\
\text { Delillerim }\end{array}$} & Üçü arasındaki tutarlılık & & & & & 31 \\
\hline 32 & & Soruyu cevaplandırmaya yönelik mi? & & & & & 32 \\
\hline 41 & \multirow{6}{*}{$\begin{array}{l}\text { Soru İddia } \\
\text { Delil Üçgeni }\end{array}$} & Üçü arasındaki tutarlılık & & & & & 41 \\
\hline 42 & & İddia ile soru arasındaki tutarlılık & & & & & 42 \\
\hline 43 & & Delillerle iddialar arasındaki tutarlılık & & & & & 43 \\
\hline 44 & & İddiayı destekleyen delillerin sayısı & & & & & 44 \\
\hline 45 & & Geliştirilen argümanın büyük düşünce* tutarlılığ $1^{* *}$ & & & & & 45 \\
\hline 46 & & Geliştirilen argümanın akla yatkınlığ $1^{* *}$ & & & & & 46 \\
\hline 51 & \multirow{2}{*}{$\begin{array}{l}\text { İddia } \\
\text { Okuduklarım } \\
\text { ve iddialarım }\end{array}$} & Kaynaktan elde edilen bilgilerin iddia ile tutarlılığ & & & & & 51 \\
\hline 52 & & $\begin{array}{l}\text { Kaynaktan elde edilen bilgiler ışı ğında bir } \\
\text { kompozisyon oluşturabilmiş mi? }\end{array}$ & & & & & 52 \\
\hline 61 & \multirow{2}{*}{$\begin{array}{l}\text { Başlangıç } \\
\text { Düşüncesi } \\
\text { Yansımalar }\end{array}$} & Yansımaların başlangıç düşüncesi ile tutarlılığı & & & & & 61 \\
\hline 62 & & $\begin{array}{l}\text { Değişmesinin ya da değişmemesinin nedenini ifade } \\
\text { edebilmiş mi? }\end{array}$ & & & & & 62 \\
\hline
\end{tabular}

